\title{
Nitrate Reductase Activity of Kleingrass (Panicum colora- tum L.) during Drought in the Northern Chihuahuan Desert
}

\author{
IAN M. RAY AND WILLIAM B. SISSON
}

\section{Abstract}

Plant nitrate (NO5- $\mathrm{N}_{\mathbf{3}}$ ) uptake rates are often low in desert environments because soil nitrogen levels are typically low, and mineralization and nitrification of nitrogen is moisture-dependent. During drought, leaf tissue $\mathrm{NO}_{\overline{3}}-\mathrm{N}$ levels toxic to graxing animals can result because the enxyme responsible for $\mathrm{NO}_{3}^{-}-\mathrm{N}$ reduction (nitrate reductase; NR) is repressed during plant water stress. Seasonal leaf $\mathrm{NR}$ activity (in vivo), and $\mathrm{NO}_{3}^{-}-\mathrm{N}$, total nitrogen, and leaf water (\%) content of kleingrass (Panicum coloratum L.) plants growing in situ in the northern Chihuahuan Desert were determined. Total precipitation during the April through November growing season $(11.5 \mathrm{~cm})$ was $40 \%$ less than the long-term average $(19 \mathrm{~cm})$. This drought resulted in low $\mathrm{NR}$ activity, repressed plant growth, and water-stressed plants through most of the growing season. Seasonal and diumal leaf NR activities were positively correlated $(P<.05)$ with leaf water contents $(\%)$ and leaf water potentials, respectively. The latter correlation was significant only with young leaf tissue. Young leaf tissue reduced $29.6 \mu \mathrm{mol} \mathrm{NO} \overline{3}-$ $\mathrm{N} \cdot \mathrm{gDW}^{\mathrm{P}}$ on $14 \mathrm{July}$ when leaf water potentials exceeded -3.0 $\mathrm{MPa}$. On $18 \mathrm{May}, 7.1 \mu \mathrm{mol} \mathrm{NO}_{3}^{-}-\mathrm{N} \cdot \mathrm{gDW}^{-1}$ were reduced when older leaf tissue was present and leaf water potentials did not exceed -3.0 MPa. Leaf $\mathrm{NO}_{\overline{3}}-\mathrm{N}$ accumulated to levels toxic to livestock during August, September, and October. The stem plus leaf sheath component of the aboveground biomass was the primary site for NR activity, and nitrogen and biomass allocation during 6 phenological stages (second through fifth leaf stages, and boot and immature seed stages). Immature seeds comprised only $12.3 \%$ of the aboveground biomass and possessed $29.9 \%$ of the nitrogen and $62.2 \%$ of the total capacity of $N \mathbf{O}_{\mathbf{3}}-\mathrm{N}$ reduction.

Frequent drought, low annual precipitation, and soil nitrogen levels are important factors that limit plant productivity and diversity in desert environments. Because soil nitrogen distribution and availability are closely correlated with soil biological activity, and, hence, soil moisture and temperature, periods of drought impose quantitative limitations on both soil moisture and nitrogen availability. Although many drought-adaptive attributes have been identified in plants (Blum 1983), an ability to compete for limited soil nitrogen $\left(\mathrm{NO}_{\overline{3}}-\mathrm{N}\right)$ during drought and reduce it by continued nitrate reductase (NR) activity might be particularly important for drought tolerance. Although $\mathrm{NH}_{4}{ }^{+}$is present in desert soils, exchangeable levels may be insufficient to supply plant needs. (Wallace et al. 1978), and desert perennial plants appear to take up No $\overline{3}-\mathrm{N}$ preferentially (Kirkby 1969).

The initial step in the metabolism of $\mathrm{NO}_{\overline{3}}-\mathrm{N}$ to other nitrogenous compounds is accomplished by NR. The level and activity of this enzyme is, therefore, the rate-limiting step. Activity of NR is deleteriously affected by many factors that include: plant water

The authors are a graduate research assistant, Department of Agronomy, University of Wisconsin, Madison, Wis.; and plant physiologist, Jornada Experimental Range, ARS, USDA, Department of Animal and Range Sciences, New Mexico State University, Las Cruces 88003 . At the time of the research, Ray was an undergraduate student majoring in agricultural biology, Entomology and Plant Pathlogy Department, New Mexico State University, Las Cruces.

The authors are grateful to Dr. Glyn O. Throneberry, Entomology and Plant Pathology Department, New Mexico State University, for providing laboratory and greenhouse space and equipment needed to complete this study. Appreciation is also extended to M.L. Jack Roberts for allowing the authors to maintain sample plots within kleingrass pastures on his ranch.

The use of trade names does not constitute an official endorsement or approval by the United States Department of Agriculture.

This paper is Journal Article 1208, Agricultural Experiment Station, New Mexico State University, Las Cruces 88003.

Manuscript accepted 5 May 1986. deficits, high temperature, low irradiance levels, insect damage, and overmature plant tissue (Beevers and Hageman 1980). Leaf water relations have a profound effect on the level, stability, and activity of NR because this enzyme is induced by the $\mathrm{NO}_{\mathbf{3}}-\mathrm{N}$ flux to the induction and assimilation sites (cytoplasm) rather than by the $\mathrm{NO}_{3}-\mathrm{N}$ content of leaves (Shaner and Boyer $1976 \mathrm{a}, \mathrm{b}$ ). Thus, substantial water deficits within plants, soil, and atmosphere (i.e., drought) result in low available soil nitrogen levels and repressed $\mathrm{NO}_{3}-\mathrm{N}$ uptake and reduction capacity by plants. During drought, NO $\overline{3}-\mathrm{N}$ can accumulate within plants to levels toxic to livestock (Tucker et al. 1961) when uptake exceeds reduction.

Successful introduction of new forage species into a desert environment is dependent upon many physiological attributes that include drought tolerance. An ability to compete with other plants for soil water and nutrients that are often limited is also an important component in the adaptability of forage plants to this type of habitat. The present study was undertaken to quantify seasonal $\mathrm{NO}_{3}-\mathrm{N}$ pools within kleingrass ( Panicum coloratum L.), an introduced $C_{4}$ bunchgrass, and soils and to determine the seasonal capacity for $\mathrm{NO}_{\overline{3}}-\mathrm{N}$ reduction within this species relative to soil and plant water status. A substantial reduction in precipitation ( $-40 \%$ from the long-term average) during the growing season (April through November) provided an opportunity to study the effects drought has on these nitrogen pools and their metabolism following uptake and translocation to leaves of kleingrass plants. A second objective was to partition biomass, nitrogen, and capacity for $\mathrm{NO}_{\overline{3}}-\mathrm{N}$ reduction within aboveground plant components during 6 phenological stages (second through fifth leaf stages, and boot and immature seed stages).

\section{Methods}

The seasonal nitrate reductase (NR) activity study was conducted between April and November 1983 on mature kleingrass plants growing in an experimental plot on the Jornada Experimental Range (ca. $32^{\circ} 34^{\prime} \mathrm{N}, 104^{\circ} 48^{\prime} \mathrm{W}$ ) near Las Cruces, N. Mex. The plants were initiated from seed within the plot in July 1975. Soil textures of the plot vary from fine loamy sand to sandy loam (Wink series; Typic Calciorthid). Average annual precipitation on the study site is $22.1 \mathrm{~cm}$ (52-year average). Annual precipitation during $1983(16.5 \mathrm{~cm})$ was $37 \%$ less than the long-term yearly average and resulted in a drought condition during the study period. April through November precipitation $(11.5 \mathrm{~cm}$ ) was $40 \%$ less than the long-term average $(19.0 \mathrm{~cm})$.

Four samples consisting of the youngest fully expanded leaves from 8 kleingrass plants were collected at approximately 10-day intervals during cloudless days from April through November for $\mathrm{NR}$ activity assays, and leaf water, $\mathrm{NO}_{\overline{3}}-\mathrm{N}$, and total nitrogen content determinations. Because leaf age composition of kleingrass plants varied throughout the study period, and the presence of young, recently expanded leaves were soil moisture dependent, leaf tissue samples representative of a single age group were not possible during the study. Tissue samples collected for analysis were, however, comprised of the youngest leaves present within each plant where nitrogen assimilation primarily occurs (Srivastava 1980). All tissue samples were collected within 0.5 hour of solar noon with the exception of 18 May and 14 July when 3 leaf tissue samples were collected prior to sunrise and every 1.5 hours thereafter to sunset. Tissue samples collected on 18 May and 14 July were immediately assayed for NR activity at the study site. All other samples were transported to the laboratory (approximately 
$30 \mathrm{~min}$ ) at $0^{\circ} \mathrm{C}$ in the dark for immediate NR activity analysis.

Leaf xylem pressure potentials were measured in the field using a PMS pressure bomb. Leaf water content was determined on 3 or 4 samples after drying the tissue for approximately 24 hours at $80^{\circ}$ C. Precipitation data were collected by a U.S. Weather Bureau station located within $10 \mathrm{~m}$ of the study site. Soil water was measured gravimetrically on 3 replicate samples removed from 3 randomly selected sites within the Jornada study plot at both 18-and 38-cm soil depths.

The entire aboveground biomass of 4 plants was collected at solar noon (cloudless days) during 6 phenological stages (second through fifth leaf stages, and boot and immature seed stages) between 23 and 28 July to determine the proportion each component contributed to total aboveground plant dry weight, nitrogen, and NR activity. The plants were removed from an irrigated pasture $12.5 \mathrm{~km}$ south of Las Cruces, $\mathrm{N}$. Mex.; the samples were transported to the laboratry (approximately $30 \mathrm{~min}$ ) in the dark at $0^{\circ} \mathrm{C}$ for immediate NR activity analysis. Soil textures of the pasture vary from loam to fine sandy loam (Glendale series; Typic Torrifluvent).

Nitrate reductase activity (in vivo) was determined on 4 samples during the seasonal and phenological studies, and on 3 samples during the diurnal analyses on 18 May and $14 \mathrm{July}$. The assay procedure followed that of Hageman and Hucklesby (1971) with the zinc acetate/phenazine methosulfate modification of Scholl et al. (1974). Tissue samples were incubated in the assay medium in a $\mathrm{N}_{2}$ atmosphere for 40 minutes at $30^{\circ} \mathrm{C}$. The samples were thoroughly mixed during incubation by vigorous shaking every 10 minutes. Absorbance was read at $540 \mathrm{~nm}$ and nitrite produced was calculated using standard nitrite concentrations.

Oven-dried tissue was ground to 40-mesh for determination of $\mathrm{NO} \overline{3}-\mathrm{N}$ and total nitrogen content. Two subsamples from each of 3 or 4 replicate tissue samples were digested (block digestion) and total nitrogen analyzed using the colorimetric method involving the reaction of ammonium with sodium salicylate, sodium nitroprusside, and sodium hypochlorite with absorption readings at 660 nm (Technicon Industrial Systems, Industrial Method Number $\left.334-74 \mathrm{~W} / \mathrm{B}^{+}-\mathrm{N}, 1977\right)$. Nitrate content was determined by the method of Cataldo et al. (1975). Nitrate extraction during the 1-hour incubation $\left(45^{\circ} \mathrm{C}\right.$ ) period was increased by approximately $30 \%$ by vigorously agitating the samples every 10 minutes in a vortex shaker.

\section{Diurnal NR Activity}

Diurnal NR activity of the youngest fully expanded leaves of kleingrass plants on the Jornada study site was low on 18 May 1983 (Fig. 1). There was no precipitation during the 30 days before 18 May (Fig. 2A) resulting in dry soil conditions (Fig 2B), and leaf water potentials exceeded $-2.5 \mathrm{MPa}$ during the middle 5 hours of the photoperiod (Fig. 1A). Maximum mean NR activity was 0.65 $\mu \mathrm{mol} \mathrm{NO}_{2} \cdot \mathrm{gDW}^{-1} \cdot$ hour $^{-1}$ when the mean leaf water potential was $-2.6 \mathrm{MPa}$. Because no new leaf growth occurred during the 30-day period before $18 \mathrm{May}$, low diurnal NR activity is probably the result of both old leaf tissue and water stress.

Diurnal NR activity was considerably higher on 14 July (Fig. 1B) relative to 18 May, particularly in the early morning hours prior to solar noon. Mean leaf water potentials were consistently lower on 14 July than those measured on 18 May suggesting leaf water stress was more severe on $14 \mathrm{July}$. New leaf growth was initiated after $1.3 \mathrm{~cm}$ of precipitation occurred 3 days before 14 July. High NR rates measured on $14 \mathrm{July}$ were, therefore, probably the result of high NR activity associated with young plant tissue. Minimal mean leaf water potential $(-0.61 \mathrm{MPa})$ and maximum NR activity $\left(4.96 \mu \mathrm{mol} \mathrm{NO}_{2}^{\overline{2}} \cdot \mathrm{gDW}^{-1} \cdot\right.$ hour $\left.^{-1}\right)$ occurred on $14 \mathrm{July}$ at sunrise (Fig. 1B). Leaf water potentials and NR activity decreased through the photoperiod to $-3.21 \mathrm{MPa}$ and $1.40 \mu \mathrm{mol}$ $\mathrm{NO}_{2} \cdot \mathrm{gDW}^{-1} \cdot$ hour $^{-1}$, respectively. Approximately $29.6 \mu \mathrm{mol}$ $\mathrm{NO}^{3}-\mathrm{N} \cdot \mathrm{gDW}^{-1}$ was reduced by leaf tissue during the $14 \mathrm{July}$ photoperiod and $7.1 \mu \mathrm{mol} \mathrm{NO}-\mathrm{3} \cdot \mathrm{gDW}{ }^{-1}$ on $18 \mathrm{May}$. Leaf water

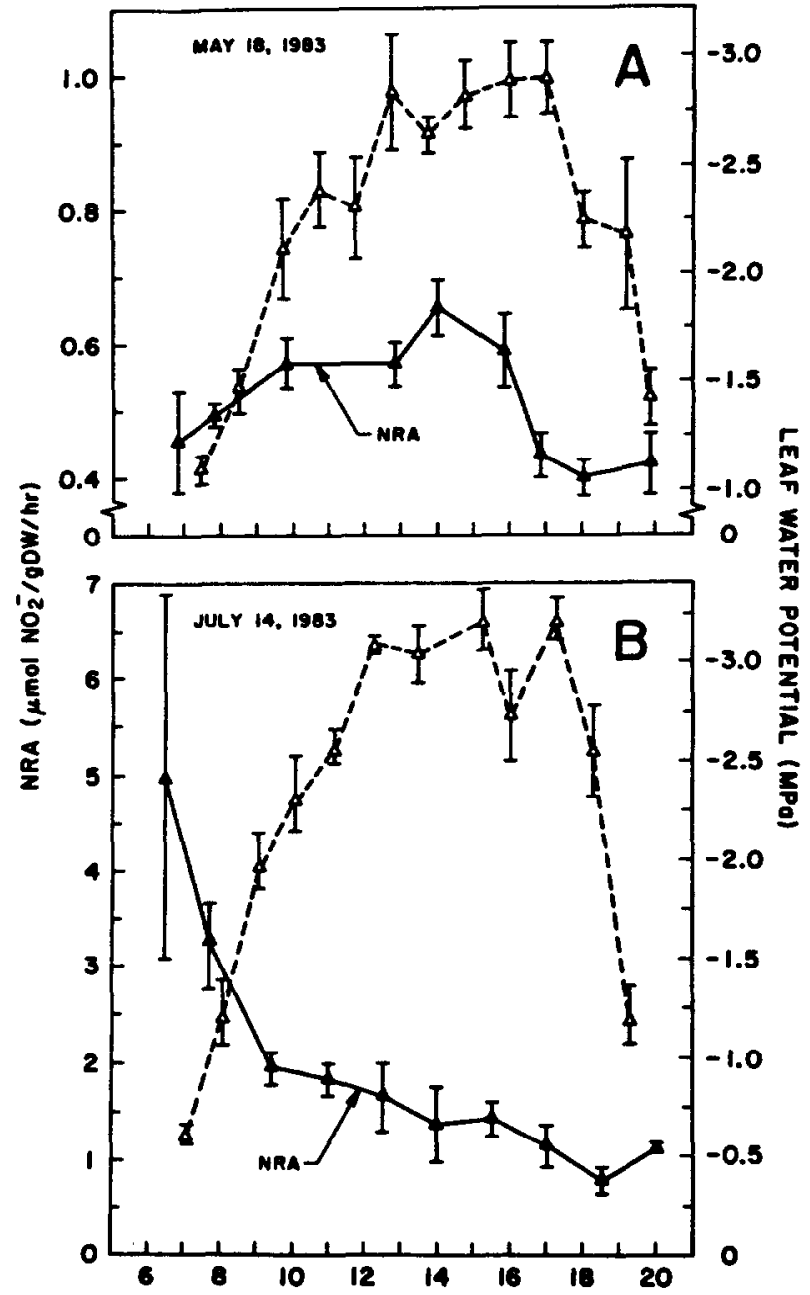

Fig. 1. Leaf nitrate reductase activity (NRA) (closed triangles) and leaf water potential (MPa) (open triangles) of kleingrass (Panicum coloratum $L$.) in the northern Chihuahuan Desert during $18 \mathrm{May}(A)$ and 14 $J u l y(B) 1983$. Vertical bars represent \pm 1 standard error of the mean, and each value is the mean of 3 replicates. Hours are Mountain Daylight Time.

potentials were statistically correlated $(r=.71 ; P<.05)$ with NR activity on 14 July while 18 May measurements were not $(P>.05)$. There were no statistically significant $(P<.05)$ relationships of leaf $\mathrm{NR}$ activity with either leaf $\mathrm{NO}_{3}-\mathrm{N}$ or total nitrogen content on either date.

\section{Seasonal NR Activity}

Maximum seasonal leaf NR activity at solar noon occurred on 14 July $\left(1.63 \mu \mathrm{mol} \mathrm{NO}{ }_{2} \cdot \mathrm{gDW}^{-1}\right.$ - hour $\left.{ }^{-1}\right), 3$ days after $1.3 \mathrm{~cm}$ precipitation (Fig. 2A) on the Jornada study site. Soil water content (Fig. 2B) at 18-cm soil depth increased from $3.6 \%$ before this rain ( $10 \mathrm{July}$ ) to $5.1 \%$ on $14 \mathrm{July}$, and leaf water content was 53.1 and $60.8 \%$ (Fig. 2B) on 11 and 14 July, respectively. There was no precipitation on the study site between 12 July and 8 Aug. A marked decline in leaf $\mathrm{NR}$ activity occurred during this period with the seasonal low in both leaf water content (40\%) and NR activity $\left(0.18 \mu \mathrm{mol} \mathrm{NO}_{2}^{-} \cdot \mathrm{gDW}^{-1} \cdot\right.$ hour $^{-1}$; Fig. 2B) on 4 Aug. Increased NR activity and leaf water content concomitant with precipitation also occurred on 27 June, 19 Aug., and 13 and 18 Sept. Following each of these temporal increases in NR activity and leaf water content (\%), NR activity declined to rates of $0.4 \mu \mathrm{mol} \mathrm{NO}_{2} \cdot \mathrm{gDW}^{-1}$ - hour ${ }^{-1}$ or less. Seasonal NR activity and leaf water content $(\%)$ were statistically $(P<.05)$, but not highly correlated $(r=.53)$.

The maximum seasonal soil water content of $10.3 \%$ at $18-\mathrm{cm}$ soil depth was measured on 12 Apr. (Fig. 2B). Young, rapidly growing leaves exhibiting a mean leaf water content of $76.1 \%$ were present on 12 Apr. Rapid depletion of soil water and minimal precipitation (Fig. 2A) thereafter resulted in soil water contents of less than 6\% 

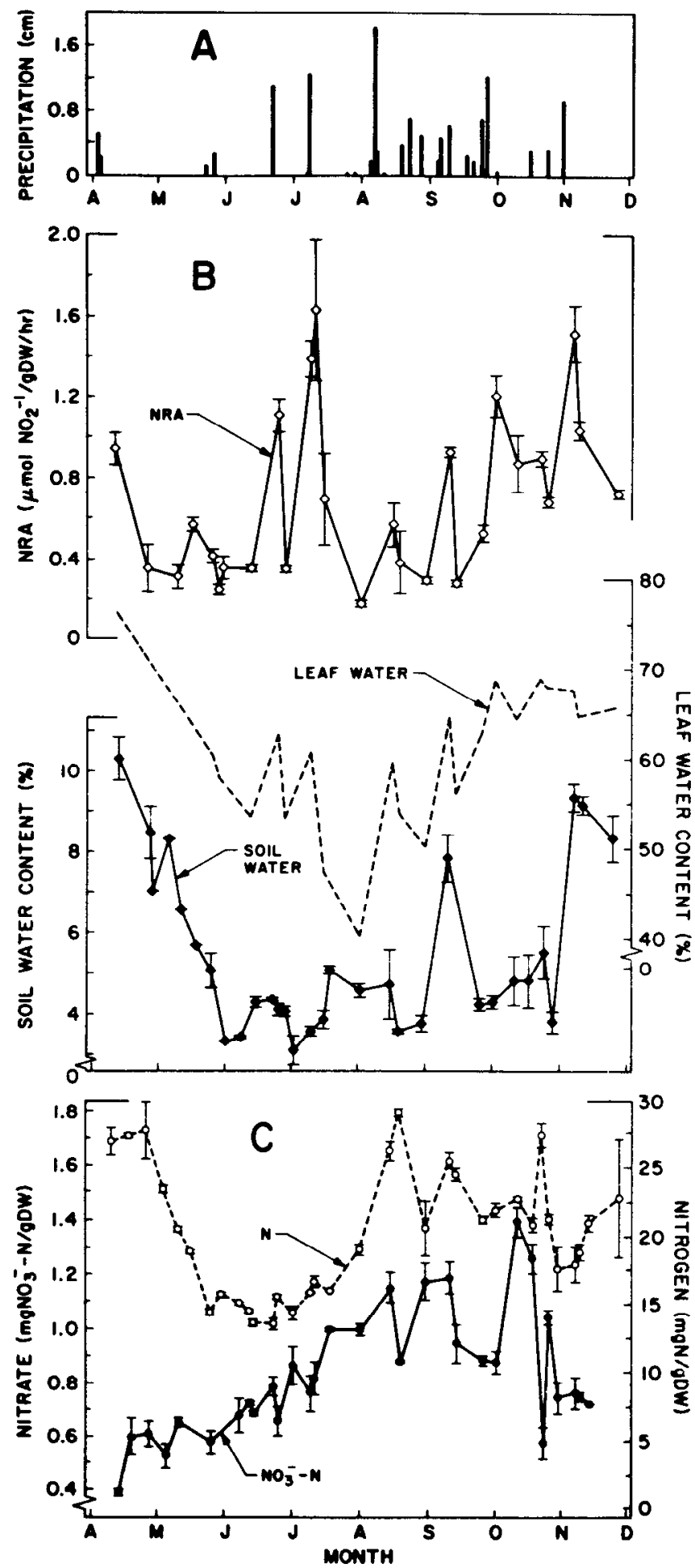

Fig. 2. Leaf nitrate reductase activity (NRA)(B) (open squares), and leaf water $(B)$ (dashed line), $\mathrm{NO}_{3}^{-}-\mathrm{N}(\mathrm{C})$ (closed circles) and total reducednitrogen ( $C$ ) (open circles) content of kleingrass (Panicum coloratum $L$.) plants during April through November growing in situ in the northern Chihauhuan Desert. Soil water content $(\%)(B)($ closed squares) at $18 \mathrm{~cm}$ soil depth and precipitation (A) are also shown. Vertical bars represent \pm 1 standard error of the mean, and each value is the mean of 3 (soil water) or $4\left(\mathrm{NRA}, \mathrm{N}\right.$ and $\left.\mathrm{NO}_{3}^{-}-\mathrm{N}\right)$ replicates. Leaf water content (\%) varied less than $7 \%$ from the mean. at a $18-\mathrm{cm}$ soil depth during June, July, and August. Soil water content exceeded 6\% during only 1 sample day in September (22 Sept.), and during November after plant growth ceased. Maintenance of relatively high leaf water contents $(>65 \%)$ in October was not reflected in elevated soil water contents at either $18-\mathrm{cm}$ (Fig. 2B) or 38-cm (data not shown) soil depth. The high leaf water contents may have, in part, been due to a low evaporative demand resulting from the low air temperatures during October.

Nitrogen content (Fig. 2C) of the youngest leaf tissue present on kleingrass plants was above $27 \mathrm{mgN} \cdot \mathrm{gDW}^{-1}$ during April and then declined to minimal levels of approximately $15 \mathrm{mgN} \cdot \mathrm{gDW}^{-1}$ during May, June, and July. This decline was probably the result of rapid tissue growth and, consequently, a dilution of tissue nitrogen. This decreasing trend in tissue nitrogen content continued until leaf growth ceased when soil water content became low in mid-May. Leaf nitrogen levels remained relatively constant until the substantial increase in August following $2.4 \mathrm{~cm}$ of precipitation. Thereafter, no discernible trend in leaf nitrogen content was evident.

Leaf $\mathrm{NO}_{3}-\mathrm{N}$ levels(Fig. $2 \mathrm{C}$ ) increased from mid-April through mid-September. This increase in plant tissue $\mathrm{NO}_{3}-\mathrm{N}$ content during drought is consistent with other studies (Morilla et al. 1973, Sisson and Throneberry 1986). Leaf $\mathrm{NO}_{3}-\mathrm{N}$ accumulated to levels toxic to livestock $\left(>0.5 \% \mathrm{NO}^{-}-\mathrm{N} \cdot \mathrm{gDW}^{-1}\right.$; Tucker et al. 1961) in August (18 Aug.), September 2 and 13 Sept.), and October (14 and 21 Oct.). Measurable levels of $\mathrm{NO}_{3}-\mathrm{N}$ were not found within the April through November soils samples removed from either the 18or 38-cm soil depths.

\section{Partition of Plant Biomass and NR Activity}

The stem plus leaf sheaths component exceeded $50 \%$ of the aboveground biomass of kleingrass plants on the irrigated pasture study site during all 6 phenological stages (second through fifth leaf stages, and boot and immature seed stages) except for the third leaf stage (Fig. 3). This component reduced a minimum of $11.7 \%$ of the

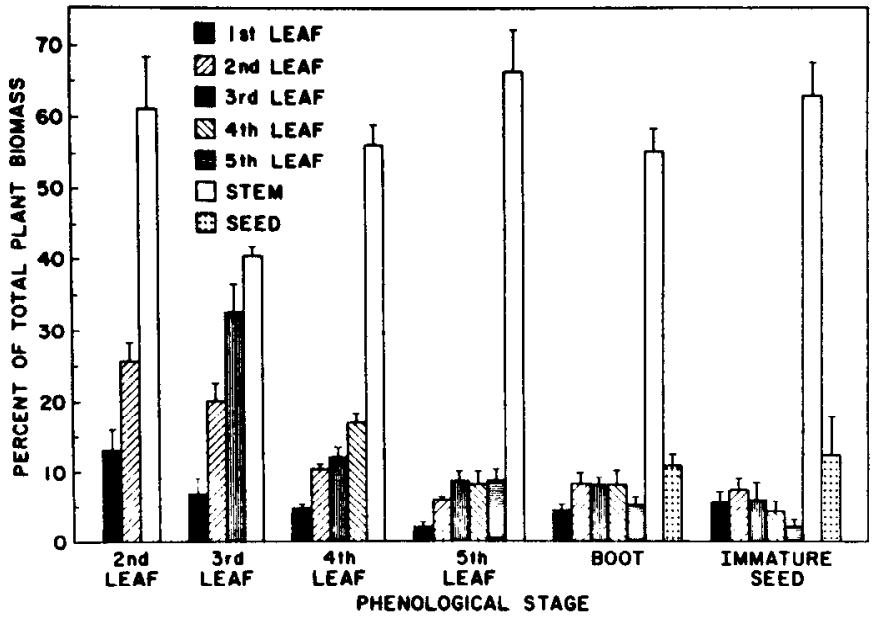

Fig. 3. Percent of total plant biomass of the aboveground components of kleingrass (Panicum coloratum $L$.) growing in an irrigated pasture in the northern Chihuahuan Desert for the second, third, fourth, and fifth leaf stages, and boot and immature seed stages. Vertical bars represent \pm 1 standard error of the mean, and each value is the mean of 4 replicates. The stem component includes the leaf sheaths.

total aboveground $\mathrm{NO}_{\overline{3}}-\mathrm{N}$ per plant during the third leaf stage, and a maximum of $42.2 \%$ when the fifth (flag) leaf matured (Fig. 4). Capacity for $\mathrm{NO}_{3}-\mathrm{N}$ reduction by the stem plus leaf sheaths increased through the fifth (flag) leaf stage and, thereafter, became less important as reproductive growth progressed. At the immature seed stage, developing seeds represented only $12.6 \%$ of the aboveground biomass but accounted for $62.2 \%$ of the capacity for $\mathrm{NO}_{3}-\mathrm{N}$ reduction per plant. Thus, seeds become a major sink for $\mathrm{NO}-\mathrm{N}$ and site for its reduction during development. 


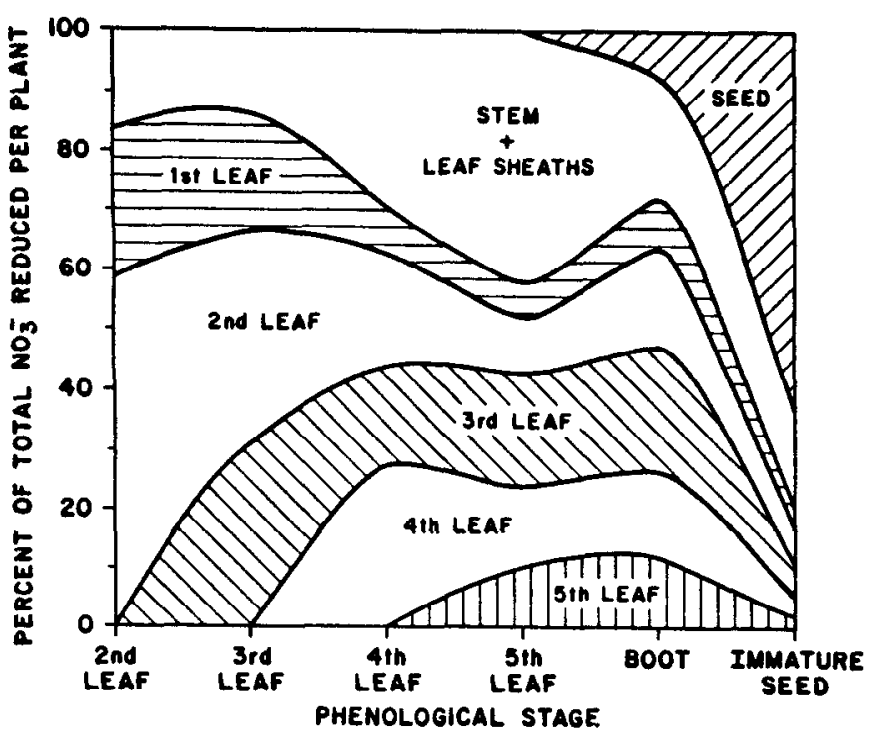

Fig. 4. Percent of the total capacity for $\mathrm{NO}_{3}^{-}-\mathrm{N}$ reduction within each of the aboveground components of kleingrass (Panicum coloratum L.) growing in an irrigated pasture in the northern Chihuahuan Desert during the second, third, fourth, and fifth leaf stages, and boot and immature seed stages. Each value represents the mean of 4 replicates, and the standard errors of the mean ranged from 2.0 to 9.8 .

Leaves 2 through 4 possessed the capacity to reduce at least $28 \%$ (range of 28 to $59 \%$ ) of the aboveground $\mathrm{NO}_{3}-\mathrm{N}$ reduced per plant when full leaf expansion was initially achieved (Fig. 4). Thereafter, capacity to reduce $\mathrm{NO}_{\overline{3}}-\mathrm{N}$ by these leaves diminished to a minimum at the immature seed stage. The fifth (flag) leaf possessed the highest NR activity on a $\mathrm{gDW}$ basis $\left(\bar{x}=0.98 \mu \mathrm{mol} \mathrm{NO}_{2}{ }^{-} \cdot \mathrm{gDW}^{-}\right.$ ${ }^{1}$. hour ${ }^{-1}$ ) of the aboveground components when it achieved full expansion. Its small biomass $(2.2 \%$ of the total aboveground plant biomass), however, resulted in the fifth leaf being of minor importance relative to $\mathrm{NO}_{3}-\mathrm{N}$ reduction capacity within the entire aboveground biomass of each plant.

Total nitrogen allocated to each aboveground component of kleingrass during 6 phenological stages is shown in Fig. 5. Nitrogen

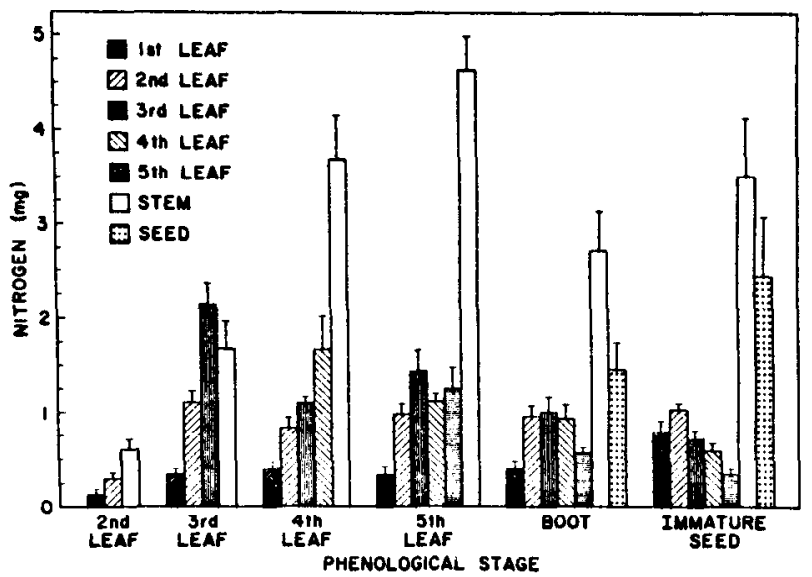

Fig. 5. Allocation of nitrogen ( $m g$ ) within each of the aboveground components of kleingrass (Panicum coloratum L.) growing in an irrigated pasture in the northern Chihuahuan Desert during the second, third. fourth, and fifth leaf stages, and boot and immature seed stages. Veritical bars represent \pm 1 standard error of the mean and each value represents the mean of 3 or 4 replicates.

content of the stem plus leaf sheaths was lower than the other plant components on a $\mathrm{mgN} \cdot \mathrm{gDW}^{-1}$ basis. The large biomass allocated to the stem plus leaf sheaths (Fig. 3), however, resulted in this component exhibiting the highest nitrogen content during all phenological stages evaluated, except the third leaf stage. Reallocation of nitrogen from leaves to other aboveground plant components was indicated by decreasing leaf nitrogen content following full leaf expansion. Developing seed possessed 10.8 and $12.3 \%$ of the aboveground biomass during the boot and immature seed stages (Fig. 3), respectively, and possessed 18.1 (boot stage) and $25.9 \%$ (immature seed) of the total aboveground nitrogen.

\section{Discussion}

Nitrate nitrogen $\left(\mathrm{NO}_{\overline{3}}-\mathrm{N}\right)$ levels are generally low in desert soils (Nishita and Haug 1973, Charley and West 1975) and concentrations are largely dependent upon season (Rychert and Skujins 1973). Desert soil NO$\overline{3}-\mathrm{N}$ concentrations commonly range between 0 to $4 \mathrm{ppm}$ (Wallace et al. 1978). During this study, detectable levels of $\mathrm{NO}_{3}-\mathrm{N}$ were not found at either $18-$ or $38-\mathrm{cm}$ soil depth. Wallace et al. (1978), recalculating the data of Nishita and Haug (1973), demonstrated that depth of rainfall penetration and root distribution primarily influenced $\mathrm{NO}_{3}-\mathrm{N}$ distribution in desert soils. Although soil microarthropods can decompose litter when soils are quite dry (Parker et al. 1984), mineralization and nitrification of soil nitrogen is moisture-dependent (Whitford et al. 1981). Consequently, absence of detectable soil $\mathrm{NO}_{\overline{3}}-\mathrm{N}$ levels is probably due to the dry soils prevalent during most of the study. Nevertheless, $\mathrm{NO}_{\overline{3}}-\mathrm{N}$ levels did increase in kleingrass leaves (Fig. 2) from April through August. Uptake of $\mathrm{NO}_{\overline{3}}-\mathrm{N}$ and its translocation to leaves can, therefore, be inferred and at rates exceeding its reduction by NR within leaves. These increases in aboveground plant tissue $\mathrm{NO}_{3} \overline{-}-\mathrm{N}$ during drought are consistent with results of other studies and can be partially attributed to a decline in NR stability, synthesis, and activity during water stress (Morilla et al. 1973, Sisson and Throneberry 1986).

Leaf age was found in this (Fig. 1A, 1B, 4) and other studies (Harper and Hageman 1972, Srivastava 1980) to influence NR activity. Maximal NR activity is typically associated with young plant tissue, and a decline in activity accompanies tissue aging and senescence. Because NR induction in leaf tissue depends on the ability to synthesize proteins, repressed NR activity that accompanies leaf tissue aging is the result of a reduction or loss of protein synthesizing capacity (Srivastava 1980). The presence of young leaf tissue on 14 July (Fig. 1B) resulted in a reduction of $29.6 \mu \mathrm{mol}$ $\mathrm{NO}_{3}^{-}-\mathrm{N} \cdot \mathrm{gDW}^{-1}$ as compared to $7.1 \mu \mathrm{mol} \mathrm{NO}-\mathrm{N} \cdot \mathrm{gDW}^{-1}$ on 18 May (Fig. 1A) when old leaf tissue was present. Higher NR activity associated with young leaves on 14 July occurred even though leaf water stress, as indicated by mean leaf water potentials, was more severe on 14 July than on 18 May.

Allocation of biomass (Fig. 3) and nitrogen (Fig. 5) within the aboveground components of kleingrass was similar through 6 phenological stages (second through fifth leaf stages, and boot and immature seed stages). Consequently, nitrogen content and total aboveground biomass were significantly $(P<.01)$ related by the regression equation, Nitrogen $=10.36+3.23 \ln B$, where $B$ is total aboveground biomass at each phenological stage. More than $50 \%$ of the aboveground biomass was allocated to the stem plus leaf sheaths component during all but the third leaf stage. Although this component had the lowest total nitrogen on a per unit weight basis, its large biomass resulted in this component exhibiting the highest nitrogen content during all but the third leaf stage. During reproductive growth, developing seeds became an important sink for nitrogen, a probable site for nitrogen reallocation from other aboveground components, and they possessed over $60 \%$ of the aboveground capacity to reduce $\mathrm{NO}_{\overline{3}}-\mathrm{N}$ (Fig. 4). Thus, significant amounts of reduced-nitrogen and capacity for $\mathrm{NO}_{\overline{3}}-\mathrm{N}$ reduction are allocated to developing seeds during the period of reproduction.

Leaf water contents and leat water potentials were statistically correlated $(P<.05)$ with NR activity on a seasonal (Fig. 2) and diurnal (14 July, Fig. 1) basis, respectively. This dependence on leaf water status results because NR is induced by the flux of $\mathrm{NO}_{\overline{3}}-\mathrm{N}$ 
within plant tissue (Shane and Boyer 1976 a, b, Beevers and Hageman 1980). During drought, therefore, reductions in $\mathrm{NO}_{\overline{3}}-\mathrm{N}$ uptake and translocation, and concomitant decreases in transpiration lower the NR substrate ( $\mathrm{NO}_{\overline{3}}-\mathrm{N}$ ) flux and cause a reduction in NR synthesis and activity. The NO$\overline{3}-\mathrm{N}$ storage pool-probably within the vacuole (Beevers and Hageman 1980) - is not readily translocated and is, therefore, not capable of inducing NR synthesis and activity. As a result, levels of $\mathrm{NO}_{3}-\mathrm{N}$ toxic to livestock can accumulate during drought when uptake exceeds reduction. Nitrate nitrogen accumulated within the leaf tissue of kleingrass during most of the growing season (Fig. 2C), and toxic levels $\left(>0.5 \% \mathrm{NO}_{3}-\mathrm{N} \cdot \mathrm{gDW}^{-1}\right.$, Tucker et al. 1961) were present during August, September, and October.

Soil- and plant-water deficits associated with a period of extended drought repress many, if not all, processes associated with $\mathrm{NO}_{\overline{3}}-\mathrm{N}$ availability within soils, the capacity of plant roots to take up $\mathrm{NO}_{\overline{3}}-\mathrm{N}$, translocation of $\mathrm{NO}_{3}-\mathrm{N}$ to aboveground $\mathrm{NR}$ sites and its reduction. Survival of kleingrass, and its continued ability to take up soil $\mathrm{NO}_{3}^{-}-\mathrm{N}$ and translocate and reduce it during drought suggests that this plant is adapted to the northern Chihuahuan Desert. The tendency to accumulate $\mathrm{NO}_{\overline{3}}-\mathrm{N}$ within leaves during drought may limit its introduction into arid rangelands. However, the elevated $\mathrm{NO}_{\overline{3}}^{-} \mathrm{N}$ levels found in the present study should be investigated further concerning livestock toxicity when kleingrass is consumed alone or as a component of the overall daily forage intake.

\section{Literature Cited}

Beevers, L., and R.H. Hageman. 1980. Nitrate and nitrite reduction. p. 115-168. In: B.J. Miflin (Ed.). The Biochemistry of Plants. A Comprehensive Treatise. Vol. 5, Amino Acids and Derivatives. Academic Press, New York, N.Y.

Blum, A. 1983. Genetic and physiological relationships in plant breeding for drought resistance. Agr. Water Manage. 7:195-205.

Cataldo, D.A., Haroon, M., Schrader, L.E., and V.L. Youngs. 1975. Rapid colorimetric determination of nitrate in plant tissue by nitration of salicylic acid. Comm. Soil Sci. Plant Anal. 6:71-80.

Charley, J.L., and N.E. West. 1975. Plant-induced soil chemical patterns in some shrub-dominated semi-desert ecosystems in Utah. J. Ecol. 63:945-963.

Hageman, R.H., and D.P. Hucklesby. 1971. Nitrate reductase from higher plants. Meth. Enzymol. 23:491-503.
Harper, J.E., and R.H. Hageman. 1972. Canopy and seasonal profiles for nitrate reductase in soybeans (Glycine max L. Merr.). Plant Physiol. 49:146-154.

Kirkby, E.A. 1969. Ion uptake and ionic balance in plants in relation to the form of nitrogen nutrition. p. 215-235. In: I.H. Rorison (Ed.). Ecological Aspects of the Mineral Nutrition of Plants. Blackwell Scientific Pub., Oxford, England.

Morilla, C.A., J.J. Boyer, and R.H. Hageman. 1973. Nitrate reductase activity and polyribosomal content of corn (Zea mays $\mathrm{L}$.) having low water potentials. Plant Physiol. 51:817-824.

Nishita, N., and R.M. Haug. 1973. Distribution of different forms of nitrogen in some desert soils. Soil Sci. 116:51-58.

Parker, L.W., P.F. Santos, J. Phillips, and W.G. Whitford. 1984. Carbon and nitrogen dynamics during the decomposition of litter and roots of a Chihuahuan Desert annual, Lepidium lasiocarpum. Ecol. Monog. 54:339-359.

Rychert, R.C., and J. Skujins. 1973. Microbial activity in arid soils. Utah Sci. 34:96-98.

Scholl, R.L., J.E. Harper, and R.H. Hageman. 1974. Improvements of the nitrate color development in assays of nitrate reductase by phenazine methosulfate and zinc acetate. Plant Physiol. 53:825-828.

Shaner, D.L., and J.S. Boyer. 1976a. Nitrate reductase activity in maize (Zea mays L.) leaves. I. Regulation by nitrate flux. Plant Physiol. 58:499504.

Shaner, D.L., and J.S. Boyer. 1976b. Nitrate reductase activity in maize (Zea mays L.) leaves. II. Regulation by nitrate flux at low leaf water potential. Plant Physiol. 58:505-509.

Sisson, W.B., and G.O. Throneberry. 1986. Seasonal nitrate reductase activity of 3 genotypes of Atriplex canescens in the northern Chihuahuan Desert J. Ecol. 74:579-589.

Srivastava, H.S. 1980. Regulation of nitrate reductase activity in higher plants. Phytochem. 19:725-733.

Tucker, J.M., D.R. Cordy, L.J, Berry, W.A. Harvey, and T.C. Fuller. 1961. Nitrate poisoning in the livestock. Univ. California Agr. Exp. Sta. Ext. Serv. Circ. 506.

Wallace, A., E.M. Romney, G.E. Kleinkopf, and S.M., Souff. 1978. Uptake of mineral forms of nitrogen by desert plants. p. 130-151. In:N.E. West and J. Skujins (Ed.). Nitrogen in Desert Ecosystems. Dowden, Hutchinson \& Ross, Inc. Stroudsburg. Penn.

Whitford, W.G., D.W. Freckman, P.F. Santos, N.Z. Elkins, and L.W. Parker. 1981. The role of nematodes in decomposition in desert ecosystems. p. 98-1 16. In: D.W. Freckman (ed.) Nematodes in Soil Ecosystems, Texas A \& M Press, College Station, Texas, USA. 